\title{
Synthesis and Extraction Studies of Calix[4]-Crown-4 Oxime Derivatives
}

\author{
Gülderen Uysal Akkuş ${ }^{1 *}$, Selma Aslan² \\ ${ }^{1}$ Department of Chemistry, Faculty of Art and Science, Afyon Kocatepe University, Afyonkarahisar, Turkey \\ ${ }^{2}$ Université d'Aix-Marseille-Faculté des Sciences-Site Etoile 52, Marseille, France \\ Email: *guakkus@gmail.com
}

How to cite this paper: Akkuş, G.U. and Aslan, S. (2017) Synthesis and Extraction Studies of Calix[4]-Crown-4 Oxime Derivatives. International Journal of Organic Chemistry, 7, 301-311.

https://doi.org/10.4236/ijoc.2017.74024

Received: August 24, 2017

Accepted: October 23, 2017

Published: October 26, 2017

Copyright $\odot 2017$ by authors and Scientific Research Publishing Inc. This work is licensed under the Creative Commons Attribution International License (CC BY 4.0).

http://creativecommons.org/licenses/by/4.0/

\begin{abstract}
The article comprises synthesis of calyx[4]-oxa-crown, and calix[4]-thia-crown compounds containing nitrile groups $(3 \mathrm{a}, \mathbf{3 b})$ and amino groups $(\mathbf{4 a}, \mathbf{4 b})$ and their corresponding oxime derivatives $(\mathbf{5} \mathbf{a}, \mathbf{5 b})$ and liquid-liquid extraction studies of these compounds. The oxime derivatives of compounds $(\mathbf{5} \mathbf{a}, \mathbf{5 b})$ have been synthesized by reacting of di-n-butylamino derivatives of calix[4]-oxa-crown, and calix[4]-thia-crown compounds (4a, 4b) with amphi-chloroglyoxime in methanol-THF. Their cation and anion transfer studies were performed by using liquid-liquid extraction procedure. It has been concluded from the observations that the compound $\mathbf{3 a}$ shows a good extraction behavior toward $\mathrm{Na}^{+}$ion in the presence of other metal cations. Whereas, its oxime derivatives transfers all of the metal cations used in the liquid-liquid extraction studies.
\end{abstract}

\section{Keywords}

Calix[4]Arene, Calixcrown, Calix-Oxime, Ion Exchange, Liquid-Liquid Extraction

\section{Introduction}

With the development of technology, environmental pollution has become an important problem today. In order to solve this problem, supramolecular chemistry develops new synthetic methods and separation techniques [1] [2] [3] [4]. In recent years, a number of studies have been carried out on the synthesis of new macrocyclic ligands that can be complex with toxic metals and anions, which play an important role in environmental contamination [5] [6] [7]. Previous studies on supramolecular chemistry have focused on two-dimensional 
complexes of neutral ionophores such as crown ethers and cryptands with some ionic molecules. In recent years, it is known that calixarenes, a phenol-formaldehyde oligomer, have a cyclic structure, such as in crown ethers, making complexes with cations, anions, and neutral molecules [8] [9] [10] [11]. Recently, new studies have been carried out to find the crown ring in the calix skeleton to combine the unique properties of both lines into a single molecule [12] [13] [14]. These compounds, called calixcrown, are formed by linking phenolic oxygens with poly (oxy) ethylene units in the molecule [1]. The first member, calixcrown compound was reported as crown ethers are combined through the bridging of the phenolic oxygen atoms of the calixarene early as 1983 and in this connection various calix[4]crowns have been reported with their host-guest properties in metal complexation, metal extraction, metal transportation, molecular switches and in ion sensing devices [12] [13] [14] [15]. Due to their highly selective metal ion recognition, which depends on the crown size, on the macrocyclic conformation (especially for calix[4]arene derivatives) and on the substituents at the upper or lower rims, the design and synthesis of these molecules have been very developed in the last few years [16]-[21].

These compounds form complexes with alkali metals [22] [23], especially cesium [24] [25] [26] are promising in the nuclear waste management, with heavy metal ions [27] [28] are useful in view of environmental protection and with lanthanides and actinides are used for their removal from industrial and nuclear waste [29].

The main aim of this study is to synthesize oxime derivatives of calix-crown compounds and to study their ion transport properties. Because the studies which related oxime derivatized calixarenes are restricted numbers [30], [31], we decided to synthesis of oxime derivatives of $4 \mathrm{a}$ and $\mathbf{4 b}$ compounds. We thought that the extraction properties of these compounds would be enhanced if we combine two properties, one of which is crown rings and the other one is oxime groups with calixarene skeleton. Because these compounds have different cavity sizes and different donor atoms, which make them potential hosts for the complexation with metal ions, neutral guests and the formation of charge transfer complexes.

\section{Experimental}

\subsection{Apparatus}

Melting points were determined on a Barnsted/Electro thermal apparatus in a sealed capillary and were uncorrected. ${ }^{1} \mathrm{H}$ NMR spectra were recorded on a Bruke Avance DPX 400 spectrometer in $\mathrm{CDCl}_{3}$ with TMS as an internal standard. IR spectra were recorded on a Perkin-Elmer 1605 FTIR System Spectrum BX spectrometer as $\mathrm{KBr}$ pellets. UV-vis spectra were obtained on a Shimadzu UV-1700 Pharma visible recording spectrophotometer. Elemental Analysis was recorded on an Elemental CHNS. 


\subsection{Materials}

Analytical TLC were performed on precoated silica gel plates $\left(\mathrm{SiO}_{2}\right.$, Merck $\mathrm{PF}_{254}$ ), while silica gel 60 (Merck, particle, size 0.040 - $0.063 \mathrm{~mm}, 230$ - 240 mesh) was used for preparative column chromatography. The drying agent employed was anhydrous sodium sulfate. All aqueous solutions were prepared with deionized water that had been passed through a Milli-Q Plus water purification system.

\subsection{Synthesis}

Compounds $1,2 \mathrm{a}$ and $\mathbf{2 b}$ were synthesized according to the procedures described in the literature [32] [33]. The other compounds $\mathbf{3} \mathbf{a}-\mathbf{5} \mathbf{b}$ employed in this work as illustrated in Scheme 1, have been synthesized as described below:
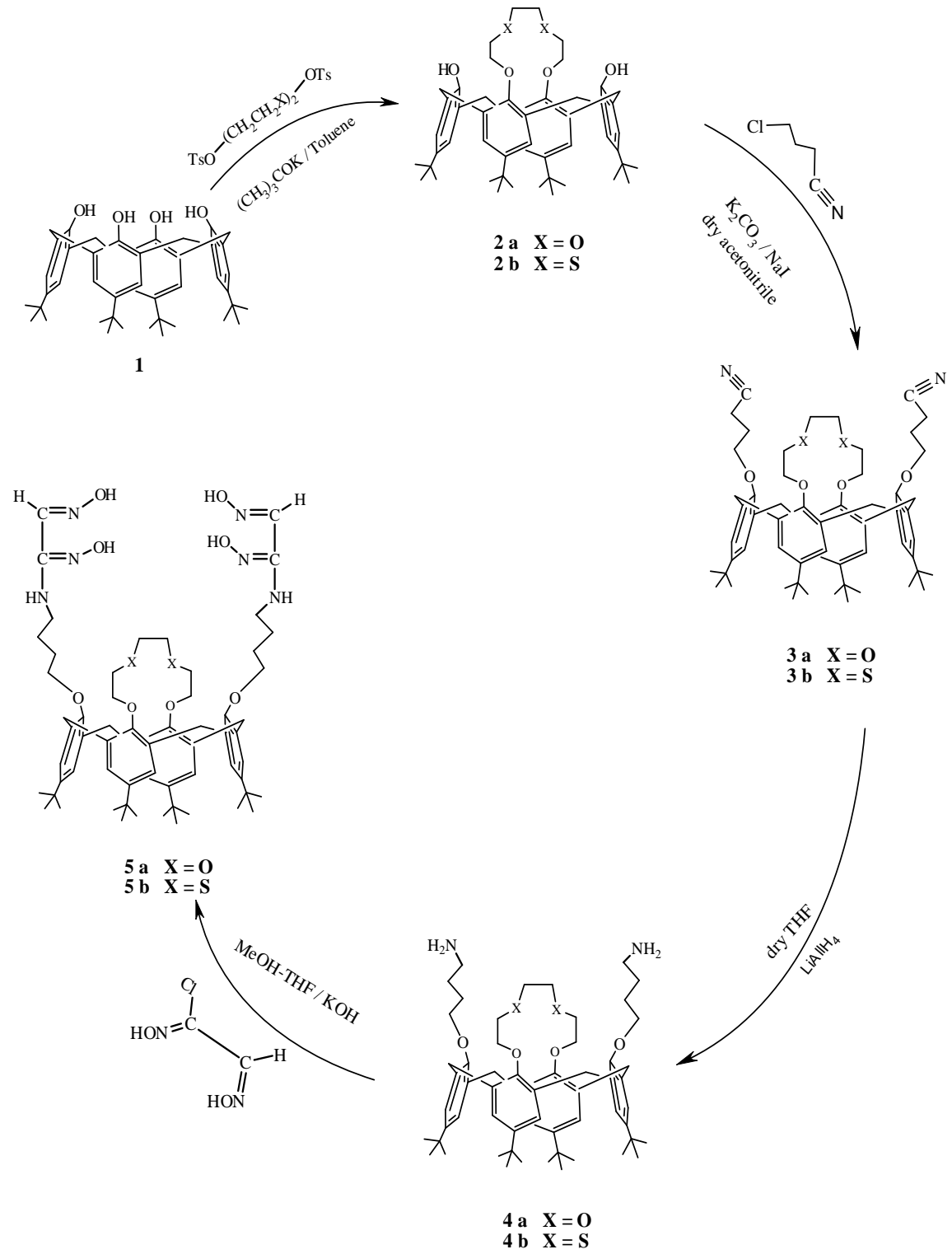

Scheme 1. Synthesis of compound 5a-5b. 


\subsubsection{5,11,17,23-Tetra-Tert-Butyl-25,27-Bis(3-Cyanopropoxy)} Calix[4]-0xacrown-4 (3a)

A mixture of compound $2 \mathrm{a}(4.00 \mathrm{~g}, 5.10 \mathrm{mmol}), \mathrm{K}_{2} \mathrm{CO}_{3}(2.81 \mathrm{~g}, 20.30 \mathrm{mmol})$, sodium iodide ( $3.00 \mathrm{~g}, 20.0 \mathrm{mmol}$ ) and 4-chlorobutyronitrile (4.0 g, $20.40 \mathrm{mmol})$ in dry acetonitrile $(200 \mathrm{~mL})$ was stirred and heated under reflux for $24 \mathrm{hr}$. The solvent was removed in vacuo and $50 \mathrm{ml} 2 \mathrm{~N} \mathrm{HCl}$ and $50 \mathrm{ml} \mathrm{CH}_{2} \mathrm{Cl}_{2}$ were added and the phases were separated. The aqueous phase was extracted two times with $30 \mathrm{ml} \mathrm{CH} \mathrm{Cl}_{2}$, the organic phases were combined dried with $\mathrm{Na}_{2} \mathrm{SO}_{4}$ and the solvent removed in vacuo. The crude product was recrystallized from methanol/ $/ \mathrm{CH}_{2} \mathrm{Cl}_{2}$ (5:1). Yield: $44 \%$, mp: $187^{\circ} \mathrm{C}$, IR $(\mathrm{KBr}) \mathrm{cm}^{-1}: 2248 \mathrm{~cm}^{-1}(\mathrm{CN}) .{ }^{1} \mathrm{H}$ $\operatorname{NMR}\left(\mathrm{CDCl}_{3}\right), 1.02-1.40$ (brs, 36H, But), $1.87-2.01\left(\mathrm{~m}, 4 \mathrm{H}, \mathrm{C}-\mathrm{CH}_{2}-\mathrm{C}\right), 2.23(\mathrm{t}$, $\left.4 \mathrm{H}, J=7 \mathrm{~Hz}, \mathrm{OCH}_{2} \mathrm{CH}_{2}\right), 3.28\left(\mathrm{t}, 4 \mathrm{H}, J=7 \mathrm{~Hz}, \mathrm{CH}_{2} \mathrm{CN}\right), 3.37(\mathrm{~d}, 4 \mathrm{H}, J=13 \mathrm{~Hz}$, $\mathrm{ArCH}_{2} \mathrm{Ar}$ ), $3.71-4.2\left(\mathrm{brm}, 12 \mathrm{H}, \mathrm{CH}_{2} \mathrm{O}\right), 4.28\left(\mathrm{~d}, 4 \mathrm{H}, J=12 \mathrm{~Hz}, \mathrm{ArCH}_{2} \mathrm{Ar}\right)$, 6.90 - $7.15(\mathrm{~m}, 8 \mathrm{H}, \mathrm{ArH})$. Calculated for $\mathrm{C}_{58} \mathrm{H}_{76} \mathrm{~N}_{2} \mathrm{O}_{6}, \mathrm{C}, 77.67 ; \mathrm{H}, 8.53 ; \mathrm{N}, 3.12$. Found: C, 77.50; H, 8.48; N, 3.07.

\subsubsection{5,11,17,23-Tetra-Tert-Butyl-25,27-Bis(3-Cyanopropoxy) Calix[4]-Thiacrown-4 (3b)}

A mixture of compound $2 \mathrm{~b}(3.5 \mathrm{~g}, 4.40 \mathrm{mmol}), \mathrm{K}_{2} \mathrm{CO}_{3}(5.73 \mathrm{~g}, 17.6 \mathrm{mmol})$, sodium iodide $(2.63,17.6 \mathrm{mmol})$ and 4-chlorobutyronitrile $(1.82 \mathrm{~g}, 17.6 \mathrm{mmol})$ in dry acetonitrile $(175 \mathrm{~mL})$ was stirred and heated under reflux for $24 \mathrm{hr}$. The reaction procedure was then proceeded according to the above described method. Usual work up afforded 3b. Yield: 54\%, mp: $147^{\circ} \mathrm{C}$. IR $(\mathrm{KBr}) \mathrm{cm}^{-1}: 2225$ $\mathrm{cm}^{-1}(\mathrm{CN}) .{ }^{1} \mathrm{H}$ NMR $\left(\mathrm{CDCl}_{3}\right), 1.00-1.41$ (brs, $\left.36 \mathrm{H}, \mathrm{Bu}^{\mathrm{t}}\right), 1.90-1.99(\mathrm{~m}, 4 \mathrm{H}$, $\left.\mathrm{CH}_{2} \mathrm{CH}_{2}-\mathrm{CH}_{2}\right), 2.34\left(\mathrm{t}, 8 \mathrm{H}, J=6 \mathrm{~Hz}, \mathrm{OCH}_{2} \mathrm{CH}_{2}\right), 3.21\left(\mathrm{t}, 4 \mathrm{H}, J=7 \mathrm{~Hz}, \mathrm{CH}_{2} \mathrm{CN}\right)$, $3.27\left(\mathrm{~d}, 4 \mathrm{H}, J=8 \mathrm{~Hz}, \mathrm{ArCH}_{2} \mathrm{Ar}\right), 3.34-3.39\left(\mathrm{~m}, 8 \mathrm{H}, \mathrm{CH}_{2} \mathrm{~S}\right), 4.17(\mathrm{~d}, 4 \mathrm{H}, J=13$ $\left.\mathrm{Hz}, \mathrm{Ar}-\mathrm{CH}_{2} \mathrm{Ar}\right), 6.82$ - 7.30 (m, 8H, ArH), Calculated for $\mathrm{C}_{58} \mathrm{H}_{76} \mathrm{~N}_{2} \mathrm{O}_{4} \mathrm{~S}_{2}, \mathrm{C}, 74.95$; H, 8.24; N, 3.01; S, 6.90. Found: C, 74.63; H, 8.16; N, 2.98 .

\subsubsection{5,11,17,23-Tetra-Tert-Butyl-25,27-Bis(4-Aminobutyoxy) Calix[4]-0xacrown-4 (4a)}

Dry THF $(50 \mathrm{~mL})$ was added in a two necked glass flask then $\mathrm{LiAlH}_{4}(0.27 \mathrm{~g}$, $7.26 \mathrm{mmol} 1: 2$ equation) was added carefully. The reaction mixture was heated until the boiling point of the solvent. A mixture of compound 3a (3.84 g, 3.63 mmol) in the warm dry THF $(100 \mathrm{~mL})$ was added dropwise over a period of 1.5 h. and reflux was continued for an additional $7 \mathrm{~h}$. At the end of this time in order to removing the $\mathrm{LiAlH}_{4}$ remaining from the reaction, distilled water (approximately $5 \mathrm{~mL}$ ) was added slowly little by little in the ice cold bath until the hydrogen gas emission ended. After the removal of most of the solvent it was taken in the separated funnel with $\mathrm{CHCl}_{3}$ then $\mathrm{pH}$ was regulated at $4-5$ with solution of $\mathrm{H}_{2} \mathrm{SO}_{4}(20 \%)$, and extracted several times with $\mathrm{CHCl}_{3}$. The combined organic layers were finally washed with distilled water, dried over $\mathrm{MgSO}_{4}$, then evaporated to dryness. The residue was recrystallization was performed in ethanol. Yield: $66 \%$, mp: $152^{\circ} \mathrm{C}$. IR ( $\left.\mathrm{KBr}\right) \mathrm{cm}^{-1}: 3400 \mathrm{~cm}^{-1}\left(\mathrm{NH}_{2}\right),{ }^{1} \mathrm{H} \mathrm{NMR}\left(\mathrm{CDCl}_{3}\right)$, $\delta 1.02-1.40$ (brs, $\left.36 \mathrm{H}, \mathrm{Bu}^{\mathrm{t}}\right), 1.78-2.10\left(\mathrm{~m}, 8 \mathrm{H}, \mathrm{CH}_{2} \mathrm{CH}_{2}\right), 2.49(\mathrm{t}, 4 \mathrm{H}, J=8 \mathrm{~Hz}$, 
$\mathrm{OCH}_{2} \mathrm{CH}_{2}$ ), $2.98\left(\mathrm{t}, 4 \mathrm{H}, J=8 \mathrm{~Hz}, \mathrm{CH}_{2} \mathrm{~N}\right), 3.36\left(\mathrm{~d}, 4 \mathrm{H}, J=7 \mathrm{~Hz}, \mathrm{ArCH}_{2} \mathrm{Ar}\right)$, 3.68 - 4.17 (brm, 12H, $\mathrm{CH}_{2} \mathrm{O}$ ), $4.32\left(\mathrm{~d}, 4 \mathrm{H}, J=12 \mathrm{~Hz}, \mathrm{ArCH}_{2} \mathrm{Ar}\right.$ ), 5.01 (s, $4 \mathrm{H}$, $\mathrm{NH}_{2}$ ), 6.87 - $7.12(\mathrm{~m}, 8 \mathrm{H}, \mathrm{ArH})$. Calculated for: $\mathrm{C}_{58} \mathrm{H}_{84} \mathrm{~N}_{2} \mathrm{O}_{6}, \mathrm{C}, 76.99 ; \mathrm{H}, 9.35 ; \mathrm{N}$, 3.09. Found: C, 76.58; H, 9.02; N, 3.05.

\subsubsection{5,11,17,23-Tetra-Tert-Butyl-25,27-Bis(4-Aminobutyoxy) Calix[4]-Thiacrown-4 (4b)}

Dry THF $(50 \mathrm{~mL})$ was added in a two necked glass flask then $\mathrm{LiAlH}_{4}(0.28 \mathrm{~g}$, $7.30 \mathrm{mmol}$ 1:2 equation) was added carefully. The reaction mixture was heated until the boiling point of the solvent. A mixture of compound $3 \mathrm{~b}$ ( $3.95 \mathrm{~g}, 3.65$ $\mathrm{mmol})$ in the warm dry THF $(100 \mathrm{~mL})$ was added dropwise over a period of 1.5 h. and reflux was continued for an additional $7 \mathrm{~h}$. The reaction procedure was then proceeded according to the described above. Usual work up afforded $\mathbf{4 b}$. Yield: $64 \%, \mathrm{mp}: 148^{\circ} \mathrm{C}$. IR ( $\left.\mathrm{KBr}\right) \mathrm{cm}^{-1}: 3412 \mathrm{~cm}^{-1}\left(\mathrm{NH}_{2}\right),{ }^{1} \mathrm{H}$ NMR (CDC13), $\delta$ 1.19 - 1.32 (brs, 36H, Bu ${ }^{\mathrm{t}}$ ), $1.8-2.17\left(\mathrm{~m}, 8 \mathrm{H}, \mathrm{CH}_{2} \mathrm{CH}_{2}\right), 2.49$ (t, $4 \mathrm{H}, J=7 \mathrm{~Hz}$, $\mathrm{OCH}_{2} \mathrm{CH}_{2}$ ), 3.01 (t, $4 \mathrm{H}, J=7 \mathrm{~Hz}, \mathrm{CH}_{2} \mathrm{~N}$ ), 3.39 (d, $4 \mathrm{H}, J=7 \mathrm{~Hz}, \mathrm{Ar}-\mathrm{CH}_{2}-\mathrm{Ar}$ ), $3.54-3.60\left(\mathrm{~m}, 8 \mathrm{H}, \mathrm{CH}_{2} \mathrm{~S}, \mathrm{CH}_{2} \mathrm{O}\right), 3.72\left(\mathrm{t}, 4 \mathrm{H}, J=7 \mathrm{~Hz}, \mathrm{CH}_{2} \mathrm{~S}\right), 4.34(\mathrm{~d}, 4 \mathrm{H}, J=13$ $\left.\mathrm{Hz}, \mathrm{Ar}-\mathrm{CH}_{2}-\mathrm{Ar}\right), 4.89$ (s, 4H, $\mathrm{NH}_{2}$ ), 6.92 - 7.11 (m, 8H, ArH). Calculated for: $\mathrm{C}_{58} \mathrm{H}_{84} \mathrm{O}_{4} \mathrm{~N}_{2} \mathrm{~S}_{2}, \mathrm{C}, 74.31 ; \mathrm{H}, 9.03 ; \mathrm{N}, 2.98 ; \mathrm{S}, 6.82$. Found: C, 74.27; H, 8.92; N, $2.85 ; \mathrm{S}, 6.70$.

\section{Synthesis of oxime derivative of compound $4 a(5 a)$}

To a solution of compound $4 \mathrm{a}(4.20 \mathrm{~g}, 5.0 \mathrm{mmol})$ in methanol-THF $(1: 4,50$ $\mathrm{mL})$ was added a solution of amphi-monochloro glyoxime $(0.12 \mathrm{~g}, 10.0 \mathrm{mmol})$ in $\mathrm{MeOH}$. Then a solution of $\mathrm{KOH}(\% 1 \mathrm{MeOH})$ was added until $\mathrm{pH}$ of the reaction medium is 5 . The reaction mixture was stirred at room temperature for $12 \mathrm{~h}$ and the solvent was evaporated in vacuo and extracted several times with diethyl ether and dried over $\mathrm{Na}_{2} \mathrm{SO}_{4}$. Evaporation of the solvent in vacuo gave the crude product (5a) after recrystallization from EtOH. Yield: $49 \%$, mp: $137^{\circ} \mathrm{C}$. IR (KBr) $\mathrm{cm}^{-1}, 3200(\mathrm{OH}) ; 1650(\mathrm{CN}) .{ }^{1} \mathrm{H}$ NMR $\left(\mathrm{CDC1}_{3}\right): \delta 0.72-0.99$ (brs, $\left.36 \mathrm{H}, \mathrm{Bu}^{\mathrm{t}}\right)$, $1.2-1.45\left(\mathrm{~m}, 8 \mathrm{H}, \mathrm{CH}_{2} \mathrm{CH}_{2}\right), 2.83\left(\mathrm{t}, 16 \mathrm{H}, \mathrm{OCH}_{2} \mathrm{CH}_{2}\right), 3.20(\mathrm{~d}, 4 \mathrm{H}, J=12 \mathrm{~Hz}$, Ar- $\mathrm{CH}_{2}-\mathrm{Ar}$ ), 3.8 - 4.4 (brm, $\left.10 \mathrm{H}, \mathrm{CH}_{2} \mathrm{~N}, \mathrm{Ar}-\mathrm{CH}_{2}-\mathrm{Ar}, \mathrm{CH}=\mathrm{N}\right), 6.37$ - 6.41 (m, $10 \mathrm{H}, \mathrm{ArH}, \mathrm{NH}), 9.0$ (s, 4H, OH). Calculated for: $\mathrm{C}_{62} \mathrm{H}_{88} \mathrm{O}_{10} \mathrm{~N}_{6}, \mathrm{C}, 69.11 ; \mathrm{H}, 8.23$; N, 7.80. Found: C, 68.05, H, 8.14; N, 7.75.

\section{Synthesis of oxime derivative of compound $4 b(5 \mathrm{~b})$}

To a solution of compound $4 \mathrm{~b}(3.5 \mathrm{~g}, 3.73 \mathrm{mmol})$ in methanol-THF $(1: 4,50$ $\mathrm{mL}$ ) was added a solution of amphi-monochloroglyoxime (0.92 $\mathrm{g}, 7.46 \mathrm{mmol})$ in $\mathrm{MeOH}$. Then a solution of $\mathrm{KOH}(1 \% \mathrm{MeOH})$ was added until $\mathrm{pH}$ of the reaction medium is 5 . The reaction mixture was stirred at room temperature for $12 \mathrm{~h}$. The reaction procedure was then proceeded according to the above described method. Usual work up afforded 5b. Yield: 52\%, mp: $151^{\circ} \mathrm{C}, \mathrm{IR}(\mathrm{KBr}) \mathrm{cm}^{-1}$, $3310(\mathrm{OH}) ; 1656(\mathrm{CN}) .{ }^{1} \mathrm{H} \mathrm{NMR}\left(\mathrm{CDC1}_{3}\right): \delta 0.91-1.41$ (brs, $\left.36 \mathrm{H}, \mathrm{Bu}^{\mathrm{t}}\right), 2.71-4.38$ (brm, $36 \mathrm{H}, \mathrm{CH}_{2} \mathrm{CH}_{2}, \mathrm{OCH}_{2} \mathrm{CH}_{2}, \mathrm{CH}_{2} \mathrm{~N}, \mathrm{Ar}-\mathrm{CH}_{2}-\mathrm{Ar}, \mathrm{CH}_{2} \mathrm{~S}, \mathrm{Ar}-\mathrm{CH}_{2}-\mathrm{Ar}, \mathrm{CH}_{2} \mathrm{~S}$, $\left.\mathrm{CH}_{2} \mathrm{O}\right), 6.94-7.20(\mathrm{~m}, 12 \mathrm{H}, \mathrm{ArH}, \mathrm{NH}, \mathrm{CH}=\mathrm{N}), 8.95$ (s, 4H, OH). Calculated for: $\mathrm{C}_{62} \mathrm{H}_{88} \mathrm{O}_{8} \mathrm{~N}_{6} \mathrm{~S}_{2}, \mathrm{C}, 67.11 ; \mathrm{H}, 7.99 ; \mathrm{N}, 7.58 ; \mathrm{S}, 5.78$. Found: C, 67.07, H, 7.84; N, 


\subsection{Liquid-Liquid Extraction Procedures}

Picrate extraction experiments were performed following Pedersen's procedure [34] A $10 \mathrm{~mL}$ of $2.5 \times 10^{-5} \mathrm{M}$ aqueous picrate and $10 \mathrm{~mL}$ of $1 \times 10^{-3} \mathrm{M}$ solution of $(2 \mathrm{a}, 3 \mathrm{a}, 4 \mathrm{a}, 5 \mathrm{a}, 2 \mathrm{~b}, 3 \mathrm{~b}, 4 \mathrm{~b}$, and $5 \mathrm{~b})$ in $\mathrm{CH}_{2} \mathrm{Cl}_{2}$ were vigorously agitated in a stoppered glass tube with a mechanical shaker for $2 \mathrm{~min}$. The two-phase systems were then magnetically stirred in a thermostated water-bath at $25^{\circ} \mathrm{C}$ for $1 \mathrm{~h}$, and finally left standing for an additional $30 \mathrm{~min}$. The concentration of picrate ion remaining in the aqueous phase was then determined spectrophotometrically. Blank experiments showed that no picrate extraction occurred in the absence of calixarene.

The alkali picrates were prepared as described elsewhere [35] by stepwise addition of a $2.5 \times 10^{-2} \mathrm{M}$ aqueous picric acid solution to a $0.14 \mathrm{M}$ aqueous solution of metal hydroxide, until neutralization which was checked by $\mathrm{pH}$ control with a glass electrode. They were then rapidly washed with ethanol and ether before being dried in vacuo for $24 \mathrm{~h}$. Transition metal picrates were prepared by stepwise addition of a $1 \times 10^{-2} \mathrm{M}$ of metal nitrate solution to a $2.5 \times 10^{-5} \mathrm{M}$ aqueous picric acid solution and shaken at $25^{\circ} \mathrm{C}$ for $1 \mathrm{~h}$.

The percent extraction $(E \%)$ has been calculated as:

$$
E \%=\left(C_{0}-C\right) / C_{0} \times 100
$$

where $C_{0}$ and $C$ are the initial and final concentrations of the metal picrate before and after the extraction, respectively.

\section{Result and Discussion}

The properties of calixarenes have been increased in the host-quest chemistry. Because these compounds transport cations, anions and neutral quests selectively. This selectivity is enhanced by functionalizing these compounds with some functional groups. Especially the selectivity is shown when the calix-crown compounds are used. As we know, oxime compounds are complex with metal cations. In this study, our aim is to enhance this present selectivity, so we have joined oxime groups with the calixcrown skeleton. To achieve the desired goal, we have synthesized $p$-tert-butylcalix[4]arene $\mathbf{1}$ as well as compounds $\mathbf{2 a}$ and $\mathbf{2 b}$ as indicated in Scheme 1 according to the previously published procedures [32], [33]. The compounds $\mathbf{3} \mathbf{a}$ and $\mathbf{3 b}$ were synthesized by refluxing $\mathbf{2} \mathbf{a}$ or $\mathbf{2} \mathbf{b}$ with 4-chlorobutyronitrile in the presence of $\mathrm{K}_{2} \mathrm{CO}_{3} / \mathrm{NaI}$ in dry acetonitrile. After purification by reprecipitation from a methanol/ $\mathrm{CH}_{2} \mathrm{Cl}_{2}$, they were obtained in $44 \%$ and 54\% yield, respectively. IR spectra showed a nitrile band at 2248 and 2225 $\mathrm{cm}^{-1}$ for $\mathbf{3 a}$ and $\mathbf{3 b}$ respectively. The ${ }^{1} \mathrm{H}$ NMR spectrum of the compounds $\mathbf{3 a}$ and $3 \mathbf{b}$ have a typical $\mathrm{AB}$ pattern for the methylene bridge protons $\left(\mathrm{ArCH}_{2} \mathrm{Ar}\right)$ of the calixarene moiety at 3.37 and $4.28 \mathrm{ppm}(J=13 \mathrm{~Hz}), 3.27$ and $4.17(J=13$ $\mathrm{Hz}$ ), for $\mathbf{3 a}$ and $\mathbf{3 b}$ respectively, indicating that both of the compounds exist in 
cone conformation.

Synthesis of the compounds $4 \mathrm{a}$ and $4 \mathrm{~b}$ were fulfilled in $66 \%$ and $64 \%$ yield respectively by the reduction of nitrile groups of $3 a$ and $3 b$ with $\mathrm{LiAlH}_{4}$ in dry THF. Completion of this reaction was followed by the IR spectroscopy indicating the disappearance of the band due to the nitrile groups at 2248 and 2225 $\mathrm{cm}^{-1}$ for $3 \mathrm{a}$ and $3 \mathrm{~b}$ respectively and the appearance of a new band at 3400 and $3412 \mathrm{~cm}^{-1}$ for the primary amine groups. The oxime derivatives of calix-crown ( $5 \mathrm{a}$ and $\mathbf{5 b}$ ) bearing butyl amine on the lower rim were synthesized by mixing compound $4 \mathrm{a}$ and $4 \mathrm{~b}$ amphi-monochloro glyoxime in the presence of $\mathrm{KOH}$ in $\mathrm{MeOH}-\mathrm{THF}$ then recrystallization from $\mathrm{MeOH}-\mathrm{CHCl}_{3}$ in $49 \%, 52 \%$ respectively. The IR spectra of compound $5 \mathbf{a}$ and $5 \mathrm{~b}$ shows a $\mathrm{C}=\mathrm{N}$-bands at $1650 \mathrm{~cm}^{-1}, 1656$ $\mathrm{cm}^{-1}$, respectively. ${ }^{1} \mathrm{H}$ NMR spectroscopy is a versatile tool for the identification of calix[4]arene conformation [33]. But from the ${ }^{1} \mathrm{H}$ NMR spectrum of the compounds $\mathbf{5 a}$ and $\mathbf{5 b}$, it is impossible to discern the conformation of calixarene moieties, because the area of $\mathrm{Ar}-\mathrm{CH}_{2}$-Ar protons are covered by the protons of $\mathrm{CH}=\mathrm{N}$.

\section{Extraction Studies}

In our previous work, we stated that oxacrown ethers are regarded as hard ionophores, on the other hand, thiacrown ethers soft ionophores [33]. Therefore, calix-oxacrowns are used alkali metal cations, on the other hand, calix-thiacrown used transition metal cations. The compounds 3a-5a were employed for transferring alkali metal cations, such as $\mathrm{Na}^{+}, \mathrm{K}^{+}$and $\mathrm{Cs}^{+}$, whereas the compounds 3b-4b for transition metal cations such as $\mathrm{Hg}^{2+}, \mathrm{Cu}^{2+}, \mathrm{Cd}^{2+}, \mathrm{Co}^{2+}$ and $\mathrm{Ni}^{2+}$. The results are summarized by graphic explanation in Figure 1 and Figure 2. These data were obtained by using dichloromethane solutions of the ligands to extract metal picrates from aqueous solution. The equilibrium concentration of picrate in aqueous phase was then determined spectrophotometrically.

From the extraction data shown in Figure 1, it was observed that calix[4]arene-oxacrown-4 2 a shows selectivity toward $\mathrm{Na}^{+}$metal ions from alkali

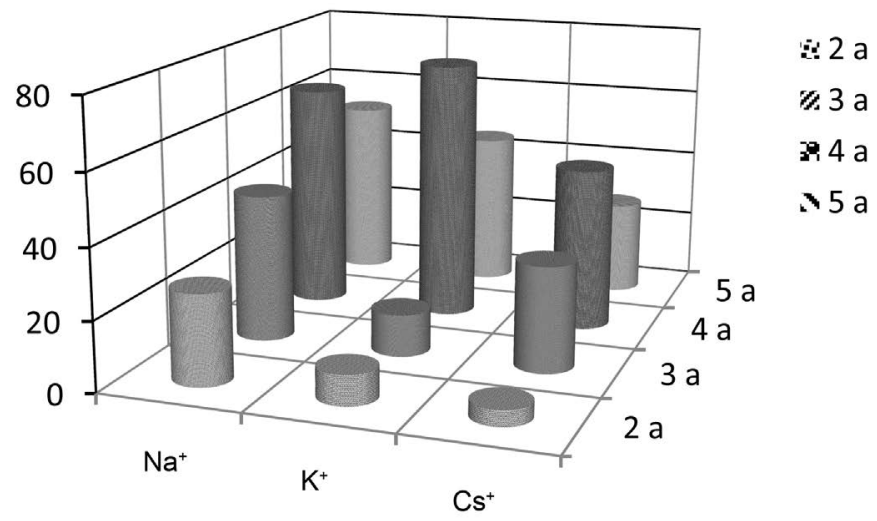

Figure 1. Extraction percentage of the metal picrates by $2 \mathrm{a}-5 \mathrm{a}$. Aqueous phase [metal nitrate $=1 \times 10^{-2} \mathrm{M}$; [picric acid] $=2.5 \times 10^{-5} \mathrm{M}$; organic phase, dichloromethane [ligand] $=1 \times 10^{-3} \mathrm{M}$ at $25^{\circ} \mathrm{C}$ for $1 \mathrm{~h}$. 


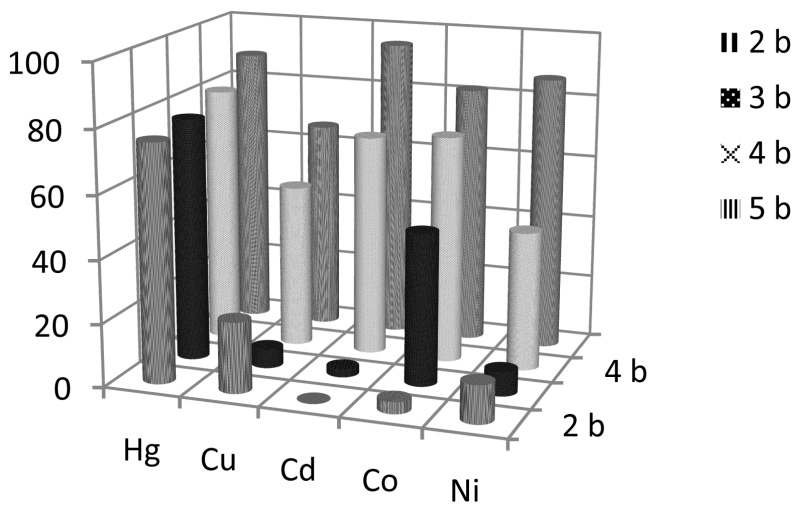

Figure 2. Extraction percentage of the metal picrates by $\mathbf{2 b}-\mathbf{5 b}$. Aqueous phase [metal nitrate $=1 \times 10^{-2} \mathrm{M}$; [picric acid] $=2.5 \times 10^{-5} \mathrm{M}$; organic phase, dichloromethane [ligand] $=1 \times 10^{-3} \mathrm{M}$ at $25^{\circ} \mathrm{C}$ for $1 \mathrm{~h}$.

metals. It has been thought that this high selectivity of $2 \mathrm{a}$ for $\mathrm{Na}^{+}$against $\mathrm{K}^{+}$is due to the appropriate size of $2 \mathrm{a}$, which have a cavity size adjusted to that between $\mathrm{Li}^{+}$and $\mathrm{Na}^{+}$. It is in agreement with our previously reported study [33] [36] and by literature [37]. Nevertheless dibutyronitrile derivative of this compound (3a) was selective for $\mathrm{Cs}^{+}$ion as well as $\mathrm{Na}^{+}$ion. In this case, $\pi$-bounds which are present in the structure of nitrile groups play an important role. Because $\pi$-bounds are regarded as soft donors according to the HSAB principle [38], and they favor complexation with the more polarizable metal ions which have larger atomic radius such a $\mathrm{Cs}^{+}$ion. As far as its oxime derivative (5a), it extracted all of the three metals to the organic phase from the aqueous phase without any selectivity. It is explained by the cation $-\pi$ interactions, since the metal ion was bound between the two opposite $\mathrm{C}=\mathrm{O}$ or $\mathrm{C}=\mathrm{N}$ ligating moieties of these compounds. Similar results were obtained by Vicens and co-workers [39] who had studied various schiff base derivatives of calix[4]arene.

It is seen from the extractions results that the composition of $p$-tert-butylcalix [4] (tia) crown-4 (2b) carries more $\mathrm{Hg}^{2+}$ cation than the others (Figure 2). This is an expected result because it carries a soft atom such as sulfur, so it is normal to be interested in a soft metal such as $\mathrm{Hg}^{2+}$. It is not correct by these compounds to only explain the transport of transition metals by the radius of the cation. This is because although the radius of the $\mathrm{Hg}^{2+}$ cation is very close to $\mathrm{Cd}^{2+}$, the extraction rates are very different $\left(\mathrm{Hg}^{2+} 75.4 \%, \mathrm{Cd}^{2+}<1.0 \%\right)$. This is in agreement with the literature [40]. It is also seen that the selectivity of $\mathrm{Hg}^{2+}$ for the nitrile derivative $3 b$ of this compound is still high, while the compound $4 b$ extracts all of the metals used more or less without any selectivity. The oxime derivative, however, extracts all the metals used from the aqueous phase to the organic phase in a good way.

\section{Acknowledgements}

We thank the Scientific and Technical Research Council of Turkey (TUBITAK-Number TBAG 105T433) for financial support of this work. 


\section{References}

[1] Memon, S., Ali Bhatti, A. and Memon, N. (2013) New Calix[4]arene Appended Amberlite XAD-4 Resin with Versatile Perchlorate Removal Efficiency. Journal of Chemical Engineering Data, 58, 2819-2827. https://doi.org/10.1021/je400554q

[2] Bhatti, A.A., Memon, S. and Memon, N. (2014) Dichromate Extraction by Calix[4]arene Appended Amberlite XAD-4 Resin. Separation Science and Technology, 49, 664-672. https://doi.org/10.1080/01496395.2013.862722

[3] Kaya, A., Alpoguz, H.K. and Yilmaz, A. (2013) Application of Cr (VI) Transport through the Polymer Inclusion Membrane with a New Synthesized Calix[4]arene Derivative. Industrial Engineering Chemistry Research, 52, 5428-5436. https://doi.org/10.1021/ie303257w

[4] Gao, J. Sun, S.P., Zhu, W.P. and Chung, T.S. (2014) Polyethyleneimine (PEI) Cross-Linked P84 Nanofiltration (NF) Hollow Fiber Membranes for $\mathrm{Pb}^{2+}$ Removal. Journal of Membrane Science, 452, 300-310.

https://doi.org/10.1016/j.memsci.2013.10.036

[5] Tabakci, M., Erdemir, S. and Yilmaz, M. (2007) Removal of Dichromate Anions with Nanofiltration-Complexation by Using Amino Calix[4]arene Derivative. Separation Science and Technology, 42, 3321-3331. https://doi.org/10.1080/01496390701626826

[6] Yilmaz, A., Tabakci, B., Akceylan, E. and Yilmaz, M. (2007) Synthesis and Dichromate Anion Extraction Ability of $p$-tert-butylcalix[4]arene Diamide Derivatives with Different Binding Sites. Tetrahedron, 63, 5000-5005.

https://doi.org/10.1016/j.tet.2007.03.138

[7] Dung, N.T. and Ludwig, R. (1999) Solvent Extraction of Heavy Metals with Macrocyclic Ligands Based on Calix[4]arenes. New Journal of Chemistry, 23, 603-607. https://doi.org/10.1039/a809771b

[8] Casnati, A., Massera, C., Pelizzi, N., Stibor, I., Pinkassik, E., Ugozzoli, F. and Ungaro, R. (2002) A Novel Self-Assembled Supramolecular Architecture İnvolving Cation, Anion and a Calix[4]arene Heteroditopic Receptor. Tetrahedron Letters, 43, 7311-7314. https://doi.org/10.1016/S0040-4039(02)01748-3

[9] Akceylan, E., Yilmaz, A. and Yilmaz, M. (2013) Synthesis and Properties of Calix[4]arene Polymers Containing Amide Groups: Exploration of Their Extraction Properties towards Dichromate and Nitrite Anions. Macromolecular Research, 21, 1091-1096. https://doi.org/10.1007/s13233-013-1152-0

[10] Memon, S., Tabakci, M., Roundhill, D.M. and Yilmaz, M. (2005) A Useful Approach toward the Synthesis and Metal Extractions with Polymer Appended Thioalkyl Calix[4] arenes. Polymer, 46, 1553-1560. https://doi.org/10.1016/j.polymer.2004.12.019

[11] Wanda, S. and Girek, T. (2010) Calixarene Complexes with Metal Ions. Journal of Inclusion Phenomena and Macrocyclic Chemistry, 66, 15-41. https://doi.org/10.1007/s10847-009-9678-7

[12] Asfari, Z., Wenger, S. and Vicens, J. (1994) Calixcrowns and Related Molecules. Journal of Inclusion Phenomena and Molecular Recognition in Chemistry, 19, 137-148. https://doi.org/10.1007/BF00708979

[13] Casnati, A., Pochini, A., Ungaro, R., Ugozzoli, F., Arnaud, F., Fanni, S. and Reinhoudt, D.N. (1995) Synthesis, Complexation, and Membrane Transport Studies of 1, 3-alternate calix[4]arene-crown-6 Conformers: A New Class of Cesium Selective Ionophores. Journal of the American Chemical Society, 117, 2767-2777. https://doi.org/10.1021/ja00115a012 
[14] Lamare, V., Bressot, C., Dozol, J.F., Vicens, J., Asfari, Z., Ungaro, R. and Casnati, A. (1997) Selective Extraction of Cesium at Tracer Level Concentration from a Sodium Nitrate Solution with Calix-Crowns. Molecular Modeling Study of the Cs+/Na+ Selectivity. Separation Science and Technology, 32, 175-191.

https://doi.org/10.1080/01496399708003193

[15] Ghidini, E., Ugozzoli, F., Ungaro, R., Harkema, S., Abu El-Fadl, A. and Reinhoudt, D.N. (1990) Complexation of Alkali Metal Cations by Conformationally Rigid, Stereoisomeric calix[4]arene Crown Ethers: A Quantitative Evaluation of Preorganization. Journal of the American Chemical Society, 112, 6979-6985. https://doi.org/10.1021/ja00175a035

[16] Mokhtari, B. and Pourabdollah, K. (2011) Effect of Crown Size and Upper Moieties in Nano-Baskets of Diacid calix[4]arene-1, 2-crowns-3, 4, 5, 6 on the Extraction of s-Block Metals. Journal of Coordination Chemistry, 64, 3081-3091. https://doi.org/10.1080/00958972.2011.613462

[17] Vicens, J. and Böhmer, V. (2012) Calixarenes: A Versatile Class of Macrocyclic Compounds. Vol. 3, Springer Science Business Media.

[18] Luo, J., Zheng, Q.Y., Chen, C.F. and Huang, Z.T. (2005) Synthesis and Optical Resolution of a Series of Inherently Chiral calix[4]crowns with Cone and Partial Cone Conformations. Chemistry-A European Journal, 11, 5917-5928. https://doi.org/10.1002/chem.200500272

[19] Xu, C., Yuan, L., Shen, X. and Zhai, M. (2010) Efficient Removal of Caesium Ions from Aqueous Solution Using a Calix Crown Ether in Ionic Liquids: Mechanism and Radiation Effect. Dalton Transactions, 39, 3897-3902.

[20] Akkus, G.U., Memon, S., Sezgin, M. and Yilmaz, M. (2009) Synthesis of calix (aza) Crown and Its Oligomeric Analogue for the Extraction of Selected Metal Cations and Dichromate Anions. CLEAN-Soil, Air, Water, 37, 109-114. https://doi.org/10.1002/clen.200800120

[21] Uysal Akku, G., Al, E. and Korcan, S.E. (2015) Selective Extraction of Toxic Heavy Metals and Biological Activity Studies using Pyrimidylthioamide Functionalised Calix[4]arene. Supramolecular Chemistry, 27, 522-526. https://doi.org/10.1080/10610278.2015.1020944

[22] Guillon, J., Léger, J.M., Sonnet, P., Jarry, C. and Robba, M. (2000) Synthesis of Cone, Partial-Cone, and 1,3-alternate 25, 27-bis [1-(2-ethyl) hexyl]-and 25, 27-bis [1-(2-tert-butoxy) ethyl] calix[4]arene-crown-6 Conformers as Potential Selective Cesium Extractants. The Journal of Organic Chemistry, 65, 8283-8289. https://doi.org/10.1021/jo001023z

[23] Li, H., Tian, D., Xiong, D. and Gao, Z. (2007) Synthesis of calix[4]crown-4 Oligomers Containing Hard and Soft Ion Binding Sites. Journal of Applied Polymer Science, 104, 3201-3205. https://doi.org/10.1002/app.26115

[24] Levitskaia, T.G., Lamb, J.D., Fox, K.L. and Moyer, B.A. (2002) Selective Carrier-Mediated Cesium Transport through Polymer Inclusion Membranes by calix[4]arene-crown-6 Carriers from Complex Aqueous Mixtures. Radiochimica Acta, 90, 43-52. https://doi.org/10.1524/ract.2002.90.1_2002.43

[25] Luo, H., Dai, S., Bonnesen, P.V., Buchanan, A.C., Holbrey, J.D., Bridges, N.J. and Rogers, R.D. (2004) Extraction of Cesium Ions from Aqueous Solutions using Calix[4]arene-bis (tert-octylbenzo-crown-6) in Ionic Liquids. Analytical Chemistry, 76, 3078-3083. https://doi.org/10.1021/ac049949k

[26] Moyer, B.A., Birdwell Jr, J.F., Bonnesen, P.V. and Delmau, L.H. (2005) Use of Macrocycles in Nuclear-Waste Cleanup: A Realworld Application of a Calixcrown in 
Cesium Separation Technology. In: Macrocyclic Chemistry, Springer Netherlands, 383-405. https://doi.org/10.1007/1-4020-3687-6_24

[27] Roundhill, D.M., Solangi, I.B., Memon, S., Bhanger, M.I. and Yilmaz, M. (2009) The Liquid-Liquid Extraction of Toxic Metals $(\mathrm{Cd}, \mathrm{Hg}$ and $\mathrm{Pb}$ ) by Calixarenes. Pakistan Journal of Analytical and Environmental Chemistry, 10, 1-13.

[28] Tabakci, M., Memon, S., Yilmaz, M. and Roundhill, D.M. (2004) Oligomeric calix[4]arene-thiacrown Ether for Toxic Heavy Metals. Journal of Polymer Science Part A: Polymer Chemistry, 42, 186-193. https://doi.org/10.1002/pola.11004

[29] Mokhtari, B., Pourabdollah, K. and Dallali, N. (2011) A Review of Calixarene Applications in Nuclear Industries. Journal of Radioanalytical and Nuclear Chemistry, 287, 921-934. https://doi.org/10.1007/s10967-010-0881-1

[30] Deligöz, H. (1999) Synthesis of New Vic-Dioxime Derivatives of p-(tert-Butyl) Calixarene and Some Metal Complexes. Organic Preparations and Procedures International, 31, 173-179. https://doi.org/10.1080/00304949909355707

[31] Deligöz, H. and Yilmaz, M. (1996) Synthesis and Ion Binding Properties of a p-Keto-oxime and a vic-Dioxime Derivative of Calix[6]arene. Synthesis and Reactivity in Inorganic and Metal-Organic Chemistry, 26, 943-953.

https://doi.org/10.1080/00945719608004345

[32] Gutsche, C.D. (1983) Calixarenes. Accounts of Chemical Research, 16, 161-170. https://doi.org/10.1021/ar00089a003

[33] Akkuş, G.U., Memon, S. and Yilmaz, M. (2002) Synthesis of Oligomeric Calix[4]arene-crowns as Novel Ionophores for Alkali and Transition Metals. Polycyclic Aromatic Compounds, 22, 1075-1086. https://doi.org/10.1080/10406630214288

[34] Pedersen, C.J. (1967) Cyclic Polyethers and Their Complexes with Metal Salts. Journal of the American Chemical Society, 89, 7017-7036. https://doi.org/10.1021/ja01002a035

[35] Inoue, K., Hirakawa, H., Ishikawa, Y., Yamaguchi, T., Nagata, J., Ohto, K. and Yoshizuka, K. (1996). Adsorption of Metal Ions on Gallium (III)-Templated Oxine Type of Chemically Modified Chitosan. Separation Science and Technology, 31, 2273-2285. https://doi.org/10.1080/01496399608001046

[36] Memon, S., Uysal, G. and Yilmaz, M. (2001) Syntheses and Binding Properties of Polymeric calix[4]crown-4. Reactive and Functional Polymers, 47, 165-174.

[37] Shinkai, S. (1991) Functionalized Calixarenes: New Applications as Catalysts, Ligands, and Host Molecules. Springer, New York, 173-198.

[38] Pearson, R.G. (1963). Hard and Soft Acids and Bases. Journal of the American Chemical Society, 85, 3533-3539. https://doi.org/10.1021/ja00905a001

[39] Seangprasertkij, R., Asfari, Z., Arnaud, F. and Vicens, J. (1994) Schiff Base p-tert-butylcalix[4]arenes. Synthesis and Metal Ion Complexation. The Journal of Organic Chemistry, 59, 1741-1744. https://doi.org/10.1021/jo00086a024

[40] Yordanov, A.T., Mague, J.T. and Roundhill, D.M. (1995) Synthesis of Heavy Metal Ion Selective calix[4]arenes Having Sulfur Containing Lower-Rim Functionalities. Inorganic Chemistry, 34, 5084-5087. https://doi.org/10.1021/ic00124a027 